\title{
Healthcare Waste Management Practices in Al Leith Hospital, Saudi Arabia
}

\author{
Alshebli Ahmed (Corresponding author) \\ Health Sciences College at Al Leith, UQU, KSA \\ Umm Al Qura University, Health Sciences College at Al Leith, KSA \\ Mecca, Saudi Arabia \\ University of Khartoum, Faculty of Public Health, Sudan \\ E-mail: aahmed@uqu.edu.sa \\ Abdulmjeed Almaki, \\ Umm Al Qura University, Health Sciences College at Al Leith, KSA \\ Mecca, Saudi Arabia \\ Faisal Alosmani, \\ Umm Al Qura University, Health Sciences College at Al Leith, KSA \\ Mecca, Saudi Arabia \\ Mohammed Alghumwi, \\ Umm Al Qura University, Health Sciences College at Al Leith, KSA \\ Mecca, Saudi Arabia \\ Saeed Bahshwan, \\ Umm Al Qura University, Health Sciences College at Al Leith, KSA \\ Mecca, Saudi Arabia \\ Ibrahim O, \\ Umm Al Qura University, Health Sciences College at Al Leith, KSA \\ Mecca, Saudi Arabia \\ Modawy Elnour Modawy \\ Umm Al Qura University, Health Sciences College at Al Leith, KSA \\ Mecca, Saudi Arabia \\ University of Khartoum, Faculty of Public Health, Sudan
}

\begin{abstract}
:
Health Care Waste: According to WHO report, the term healthcare waste is defined as all the waste generated by health-care establishments, research facilitates, laboratories, hospitals, clinics, medical research centers, pharmaceutical manufacturing plants, pharmacies, blood banks, veterinary healthcare centers and home healthcare activities (Prüss et al. 2013; Alhadlaq, 2014) .Objectives: The main objectives of this study are to assessment of the medical waste management practices of Al leith Hospital, to identify the present medical waste handling practices training and vaccination against hepatitis $\mathrm{B}$ at the Al leith hospital. Materials and Methods: This is a descriptive cross-sectional study was conducted to examine the medical waste management practices was conducted in Al leith hospital in Al leith, KSA from March to April 2019. Waste management officers or infection control officers of hospital were interviewed, to provide the following data; the number of inpatients administered on a monthly basis, vaccination hepatitis B, waste training and the storage area. The questionnaire was designed on the basis of the national regulatory framework for medical waste management and the World Health Organization's rapid assessment tool (WHO 2004), observations were made of departments, wards, related internal facilities such as storage sites, containers and tools, handling practices of medical staff common practices and detailed issues on medical waste management in hospital. SPSS Analysis
\end{abstract}


Analyses of data was performed by the use of Statistical Package for Social Science (SPSS) version.17 Software. Results: the total waste generation rate in Al leith hospital was about $2.9 \mathrm{~kg} / \mathrm{bed} / \mathrm{day}$ and it within the range of WHO, The result revealed that there is designated storage area in Al leith hospital, almost all departments $60.0 \%$ of the hospital surveyed practiced some sort of medical waste segregation, $70.0 \%$ of the health care staff were immunized against common communicable diseases, while in $3.3 \%$, they were not and $26.7 \%$ do not remember. The result of our study revealed that there was only $63.3 \%$ of workers had trained, Conclusion: The results also showed that segregation of various medical waste types in the hospital has not been conducted properly. $70.0 \%$ of the health care staff were immunized against common communicable diseases, while in $3.3 \%$, they were not and $26.7 \%$ do not remember. The study revealed the need for training and capacity building programs of all employees involved in the medical waste management .Recommendation: Improve the properly segregation of medical waste, in addition to establishing training programs on proper waste management for all healthcare workers and full coverage immunized against common communicable diseases.

Keywords: waste, healthcare, hospital, KSA

DOI: $10.7176 / \mathrm{JSTR} / 5-12-30$

\section{Introduction:}

Hospital Waste: refers to all waste generated by hospitals including infectious and non-infectious waste materials, hazardous and chemicals, biological and non-biological that discarded (Alhadlaq, 2014) . Medical Waste: Medical waste is a subcategory of hospital waste and indicates 'potentially' infectious waste that produced from healthcare facilities (Komilis and Katsafaros 2011; Alhadlaq, 2014) .

Hazardous Waste: All materials that make harm to human kind or animals or to the environment as a result of their biological, physical, or chemical characteristics (infectivity, sharpness, flammability, corrosively, and others) (Diaz and Savage, 2003) .

Management of healthcare waste is an integral part of infection control and hygiene programs in healthcare settings (Soilman and Ahmed, 2007). In another word, healthcare waste management means all activities involved in waste generation, segregation, transportation, storage, treatment and final disposal. This will confirm that inputs (funds, equipment and facilities and activities) and outputs (safe workplaces, healthy environment and healthy workers) for the safe handling and disposal of healthcare waste are in place (Muduli and Barve , 2012). Health care waste can be classified into nonhazardous or general waste: The nonhazardous health care is composed of materials similar to those found in domestic waste including wool, kitchen wastes, etc., (Mohan, et al., 2012) .

Hazardous Waste: According to WHO the 10-25\% hazardous fractions of total health care waste are usually classified into the following waste groups (Chartier, 2014). Infectious Waste: All wastes suspected to contain pathogens in sufficient quantities to cause diseases to humans. It includes discarded materials used for the diagnosis, treatment and prevention of disease as dressings, swabs, etc. This group also includes liquid waste such as urine, blood and sputum or lung secretions (Alhadlaq, 2014). Pathological Waste: Pathological waste includes tissues, blood and other waste from surgery and autopsies on patients with infectious diseases. It may also include healthy body parts that are removed during a medical procedure or produced during medical research (Pichtel,2005) .Sharps: Sharps are items that could cause cuts or wounds, including needles, scalpels and other blades, knives, saws and broken glass. These items are usually considered highly hazardous (Ananth et al.,2010) Hazardous Pharmaceutical Waste: Pharmaceutical waste includes expired, unused and contaminated pharmaceutical products, drugs, vaccines and sera that are no longer required, and need to be disposed of carefully (Schwartz et al., 2010) Genotoxic Waste: Genotoxic waste is derived from drugs used in oncology or radiotherapy units that have a high hazardous mutagenic or cytotoxic effect, vomit or urine from patients treated with cytotoxic drugs or chemicals should be considered as genotoxic (Prüss et al. 2013) .Chemical Waste: Chemical waste includes discarded chemicals that are generated during disinfecting procedures (Alhadlaq, 2014). Chemical waste includes discarded solid, liquid, and gaseous chemicals, that are generated during diagnostic and experimental work and from cleaning, housekeeping, and disinfecting procedures. Chemical waste may be hazardous (toxic; corrosive; flammable; reactive) or nonhazardous which consists of chemicals with none of the above properties (example is sugars and amino acids) (Chartier, 2014) .High Content of Heavy Metals: represent a subcategory of hazardous chemical waste and are usually highly toxic. Waste with high contents of heavy metals such as cadmium or mercury from thermometers or manometer. They are considered as a sub-group of chemical waste but they should be treated specifically. (Fu and Wang, 2011). Radioactive Waste: Radioactive waste includes 
gas, liquids and solids contaminated with radio-nuclides whose ionizing radiations have genotoxic effects. (Demirbas, 2011) .

Medical waste generation depends on several factors such as type of health care facilities, hospital specialization, available waste segregation options, seasonal variation, the number of hospital beds, and proportion of patients treated on a daily basis (Debere et al. ,2013).

\section{Materials and Methods:}

Study design: This is a descriptive cross-sectional study was conducted to examine the medical waste management practices.

Study area and population: This study was conducted in Al leith hospital in Al leith, KSA

Sampling (sample size \& sample technique)

Sample size was calculated using the Slovin's Formula

$N=\frac{n}{1+N e^{2}}$

Where

$\mathrm{n}=$ number of samples needed

$\mathrm{N}=$ population size

$\mathrm{e}=$ margin of error (use $5 \%$ or 0.05 )

Data collection method:

Waste management officers or infection control officers of hospitals were interviewed, to provide the following data; the number of inpatients administered on a monthly basis, vaccination hepatitis B, waste training and the storage area. The questionnaire was designed on the basis of the national regulatory framework for medical waste management and the World Health Organization's rapid assessment tool (WHO 2004), observations were made of departments, wards, related internal facilities such as storage sites, containers and tools, handling practices of medical staff common practices and detailed issues on medical waste management in hospital. SPSS Analysis Analyses of data was performed by the use of Statistical Package for Social Science (SPSS) version.17 Software.

\section{Results:}

Table (1): Show employees gender in Al leith Hospital, Al leith, Saudi Arabia 2019 (N=30).

\begin{tabular}{|l|l|l|}
\hline Gender & Frequency & Percent \\
\hline male & 5 & 16.7 \\
\hline female & 25 & 83.3 \\
\hline Total & 30 & 100.0 \\
\hline
\end{tabular}

Table (2): Show frequently health care waste collected from Al leith Hospital, Al leith, Saudi Arabia $2019(\mathrm{~N}=30)$.

\begin{tabular}{|l|l|l|}
\hline Frequency of collection & Frequency & Percent \\
\hline Once a day & 24 & 80.0 \\
\hline Other & 6 & 20.0 \\
\hline Total & 30 & 100.0 \\
\hline
\end{tabular}


Table (3): Show the type of container was used for sharp waste in Al leith Hospital, Al leith, Saudi Arabia $2019(\mathrm{~N}=30)$.

\begin{tabular}{|l|l|l|}
\hline What type of container is used for sharp waste? & Frequency & Percent \\
\hline Yellow Container & 28 & 93.3 \\
\hline Red Liner and Box & 2 & 6.7 \\
\hline Total & 30 & 100.0 \\
\hline
\end{tabular}

Table (4): Illustrate segregation of general waste at source in Al leith Hospital, Al leith, Saudi Arabia $2019(\mathrm{~N}=30)$.

\begin{tabular}{|l|l|l|}
\hline segregation of general waste at source & Number of employees & $\%$ \\
\hline Yes & 19 & 63.3 \\
\hline No & 6 & 20.0 \\
\hline Do not Know & 5 & 16.7 \\
\hline
\end{tabular}

Table (5): Show availability of temporary storage in Al leith Hospital, Al leith, Saudi Arabia 2019 $(\mathrm{N}=30)$.

\begin{tabular}{|l|l|l|}
\hline Availability of temporary storage & Workers number & $\%$ \\
\hline Yes & 19 & 63.3 \\
\hline No & 3 & 10.0 \\
\hline Do not Know & 8 & 26.7 \\
\hline
\end{tabular}

Table (6): Show is the healthcare waste handlers get training in waste handling? in Al leith Hospital, Al leith, Saudi Arabia 2019 (N=30).

\begin{tabular}{|l|l|l|}
\hline $\begin{array}{l}\text { Is the health care risk waste handlers get training } \\
\text { in waste handling? }\end{array}$ & Frequency & Percent \\
\hline Yes & 19 & 63.3 \\
\hline No & 11 & 36.7 \\
\hline Total & 30 & 100.0 \\
\hline
\end{tabular}


Table (7): Show vaccination against hepatitis B among health care personal handling waste in Al leith Hospital, Al leith, Saudi Arabia 2019 (N=30).

\begin{tabular}{|l|l|l|}
\hline vaccination against hepatitis B & Frequency & $\%$ \\
\hline Yes & 21 & 70 \\
\hline No & 1 & 3.3 \\
\hline Do not Know & 8 & 26.7 \\
\hline Total & 30 & 100.0 \\
\hline
\end{tabular}

Table (8): Show designated storage area for health care waste in Al leith Hospital, Al leith, Saudi Arabia $2019(\mathrm{~N}=30)$.

\begin{tabular}{|l|l|l|}
\hline $\begin{array}{l}\text { Is there a designated storage area for health } \\
\text { care waste at the facility? }\end{array}$ & Frequency & Percent \\
\hline Yes & 23 & 76.7 \\
\hline No & 7 & 23.3 \\
\hline Total & 30 & 100.0 \\
\hline
\end{tabular}

Table (9): Knowledge about healthcare waste risk plan among Al leith Hospital Health care workers, $\mathrm{Al}$ leith, Saudi Arabia 2019 (N=30).

\begin{tabular}{|l|l|l|}
\hline Knowledge about healthcare waste risk plan & Health care workers & \\
\hline Yes & 20 & 66.7 \\
\hline No & 1 & 3.3 \\
\hline Do not Know & 9 & 30.0 \\
\hline
\end{tabular}

\section{Discussion:}

A total of 76 questionnaires were sent to hospital in Al leith city, 30 of these surveys were return. Normally health care wastes are categorized into two types such as infectious and non-infectious (Saini and Dadhwal, 1995). In this study, the term " medical wastes"' refers to all types of potentially hazardous waste. Infectious waste includes all those medical wastes, which have the potential to transmit viral, bacterial or parasitic diseases. It includes both human and animal infectious wastes and waste generated in laboratories and veterinary practice.

The study revealed that the total quantity of waste generated by Al leith hospital is approximately 3500 $\mathrm{kg} / \mathrm{month}(2.9 \mathrm{~kg} / \mathrm{bed} / \mathrm{day})$.Is similar the finding in Jasem et al 2007 results (The hazardous wastes generation varied between $0.63 \mathrm{~kg} / \mathrm{bed} / \mathrm{day}$ at Al-Amiri hospital and $2.28 \mathrm{~kg} / \mathrm{bed} / \mathrm{day}$ at Al-Farwania hospital. In Japan, the hazardous waste generation rate, on an average, is $0.471 \mathrm{~kg} / \mathrm{bed}$ day, while the net medical waste generation rate is between 1.5 and $3.0 \mathrm{~kg} / \mathrm{bed}$ day. In addition, the waste generation rate in Kuwait is much lower than that of $4.5 \mathrm{~kg} / \mathrm{bed} /$ day in the USA, $4.0 \mathrm{~kg} / \mathrm{bed} / \mathrm{day}$ in Spain, $4.4-6.1 \mathrm{~kg} / \mathrm{bed} / \mathrm{day}$ in Jordan and $3 \mathrm{~kg} / \mathrm{bed} /$ day in France. However, the average hospital waste generation rates in Mexico, Saudi Arabia, Bangladesh, Venezuela and Argentina are between $1.05 \mathrm{~kg} / \mathrm{bed} / \mathrm{day}$ and $1.5 \mathrm{~kg} / \mathrm{bed} / \mathrm{day}$ ((Jasem M. Alhumoud and Hani M. Alhumoud, 2007). According to (Komilis et al.,2012) the mean unit generation rate of total medical waste from health care facilities in Greece was varied from 0.00124 $\mathrm{kg} / \mathrm{bed} /$ day (private psychiatric hospitals) to $0.718 \mathrm{~kg} / \mathrm{bed} /$ day (public university hospitals) . 
In Bangladesh, a total of $2490 \mathrm{~kg} /$ day health care waste $(0.57 \mathrm{~kg} / \mathrm{patient} / \mathrm{day}$, of which $0.21 \mathrm{~kg} / \mathrm{patient} / \mathrm{day}$ was hazardous wastes and the rest $0.36 \mathrm{~kg} /$ patient/day was non-hazardous wastes) was produced in Chittagong Medical College Hospital. The amount of health care waste produced in the hospital was positively correlated with the number of beds (Alam et al.,2008) .

A study carried out in Iran and involved 14 hospitals indicated that the health care waste generation rate was comprised of $51.6 \%$ of infectious waste, $47.2 \%$ general waste and $1.2 \%$ sharps (Bazrafshan and Mostafapoor ,2011). The generation rate in four hospitals of Nablus city, Palestine was between 0.33 and $0.84 \mathrm{~kg} /$ patient/day (Al-Khatib et al.,2009)

A Master Plan for Healthcare Waste Management in West Bank/Gaza Strip (The World Bank,2005), indicate that in 2004 a production of 2,003 kg/day (400 kg/day of hazardous waste), considering 1.306 $\mathrm{kg} / \mathrm{bed} /$ day and an occupancy rate of $80 \%(1,534$ occupied beds out of 1,917$)$.

In Jenin district, the average total hospital generation rate on an in-patient basis was of $1.96 \mathrm{~kg} / \mathrm{bed} / \mathrm{day}$, while the average hazardous waste generation rates in all surveyed hospitals was $0.85 \mathrm{~kg} / \mathrm{bed} / \mathrm{day}$ and the average general waste generation rates in all surveyed hospitals was $1.12 \mathrm{~kg} / \mathrm{bed} / \mathrm{day}$ (Eleyan et al.,2013)

The World Health Organization (WHO, 2004) estimated the total medical waste per person per year is anywhere to be from 0.50 to $3.00 \mathrm{~kg} / \mathrm{bed} / \mathrm{day}$ in both developing and less developed countries. The study has shown that the total waste generation rate in $\mathrm{Al}$ leith hospital is about $2.9 \mathrm{~kg} / \mathrm{bed} / \mathrm{day}$ and it within the range of WHO and less than (Dehghani,.et al ,2008) the average of waste generation rates in the hospitals was estimated to be $4.42 \mathrm{~kg} / \mathrm{bed} /$ day .

WHO recommends that medical waste be segregated into the appropriate containers/ bags at the point of generation ,the study revealed that almost all departments $(60.0 \%)$ of the hospital surveyed practiced some sort of medical waste segregation. A local study was applied in two hospitals in the Gaza strip (Sarsour et al., 2014) the results showed that $60 \%$ of participants who pointed out that hazardous and medical wastes are still handled and disposed together with domestic wastes and segregation was applied only for sharp waste which is collected in special sharp boxes at the beginning after usage.

Both types of wastes were collected once a day. The waste from the operation all containers kept for the collection of hazardous wastes were labeled with biohazard/cytotoxic symbols while other containers for non-hazardous wastes were not labeled (Jasem M. Alhumoud and Hani M. Alhumoud, 2007)

In Al leith hospital both red bags and general trash bags were present in all rooms in addition to a sharp container mounted on the wall of the rooms. The type of container was used for sharp waste in Al leith Hospital is about $93.3 \%$ used yellow container and about $6.7 \%$ used red liner and box.

Medical waste must be stored before collection and final disposal, it must be collected on a regular daily basis to the area where the larger containers are kept before removal to the central storage area (Almuneef and Memish, 2003). The central storage area should be sized according to the volume of waste generated as well as the frequency of collection. Storage time should not exceed 24 - 48 hours especially in countries that have a warm and humid climate (Pichtel, 2005) .

The result revealed that there is designated storage area in Al leith hospital this agree with (Pruss et al., 1999) the place where the hospital waste is kept before transporting to the final disposal site is termed as a temporary waste storage area. Unfortunately $23.3 \%$ says there is no storage area in the hospital but it is agood when compare with a local study was applied in two hospitals in the Gaza strip (Sarsour et al., 2014) around $47 \%$ of respondents do not know where medical storage place is. Segregation: According to (Cheng et al.,2009), segregation refers to separation of waste into designated categories. The safe management of medical waste can be obtained by segregation and identification of the waste at the point of generation, then it can be sent through the appropriate route for disposal (Abor et al., 2007; Kudoma, 2013). Therefore, it is important to have an efficient segregation system as well as designated storage area within the establishment. The appropriate way of identifying the categories of medical waste is by sorting them according to their color (Dohare et al., 2013; Alhadlaq, 2014) .

About $70 \%$ of health care staff were immunized against common communicable diseases, while in $3.3 \%$, they were not and 26.7\% were not remember compare with (Amin, Gul and Mehrab 2013) 60\% of the health care institutes, the janitors and sanitary staff were immunized against common communicable diseases, while in $40 \%$, they were not. The result illustrate that transportation always properly documented and all vehicles carry a consignment note from the Al leith hospital to the treatment facility and these agree with (Nwachukwu et al., 2013) 
Proper training must be carried out with hospital employees to develop awareness of health, safety and environmental issues (Mohee, 2005; Kumari et al.,2013). Staff members who are involved in handling waste should be provided with training in handling, segregation, storage and disposal procedures (Kudoma, 2013). The result of our study revealed that there was only $63.3 \%$ of workers had trained and its good when compare with study was applied in two hospitals in the Gaza strip (Sarsour et al., 2014) In the surveyed hospitals, there is deficiency in implementing training courses about healthcare waste management as $23 \%$ only of all study subjects had been provided with training on how to deal with medical waste. (Abdulla et al. 2008) reported that $29 \%$ of hospitals in Northern Jordan had not provided training to doctors and other personnel regarding medical waste management, $57 \%$ of the hospitals studied provided limited training for support staff (maintenance, engineers and cleaning workers). (Yong et al., 2009) in Nanjing city hospitals in China indicate that there was lack of sufficient training and education programs for all hospital staff. (Coker et al., 2009) noted that in Ibadan, Nigeria, health facilities, $59 \%$ of health workers were not trained in medical waste management.

\section{Conclusion:}

The study showed that segregation of various medical waste types in the hospital has not been conducted properly. $70.0 \%$ of the health care staff were immunized against common communicable diseases, while in $3.3 \%$, they were not and $26.7 \%$ do not remember. The study revealed the need for training and capacity building programs of all employees involved in the medical waste management .

\section{Recommendation:}

Improve the properly segregation of medical waste, in addition to establishing training programs on proper waste management for all healthcare workers full coverage immunized against common communicable diseases.

\section{References}

Abdulla, F., Qdais, H. A., \& Rabi, A. (2008). Site Investigation on Medical Waste Management Practices in Northern Jordan. Waste Management, 28(2), 450-458 .

Abor, P. A. (2007). Medical waste management at Tygerberg hospital in the Western Cape, South Africa (Unpublished Doctoral Thesis). Cape Peninsula University of Technology .

Ahmed, Rehan Hospital Waste Management inPakistan, National Committee on Solid Waste Cleansing Association, Denmark 1993.

Alam, M. M., Sujauddin, M., Iqbal, G. M. A., \& Huda, S. M. S. (2008). Report: Healthcare waste characterization in Chittagong Medical College Hospital, Bangladesh. Waste Management \& Research, 26(3), 291-296.

Alhadlaq, A. (2014). Investigation and development of a framework for medical waste management (Unpublished Doctoral Thesis). Brunel University London .

Al-Khatib, I. A., \& Sato, C. (2009). Solid health care waste management status at health care centers in the West Bank-Palestinian Territory. Waste management, 29(8), 2398-2403 .

Almuneef, M., \& Memish, Z. A. (2003). Effective medical waste management: it can be done. American journal of infection control, 31(3), 188-192 .

Amin R, Gul R, Mehrab A. Hospital waste management; practices in different hospitals of Distt. Peshawar. Professional Med J 2013;20(6): 988-994

Ananth, A. P., Prashanthini, V., \& Visvanathan, C. (2010). Healthcare waste management in Asia. Waste Management, 30(1), 154-161 . 
Bazrafshan, E., \& Mostafapoor, F. K., (2011). Survey of medical waste characterization and management in Iran: a case study of Sistan and Baluchestan Province. Waste Management \& Research, 29(4), 442-450.

Chartier, Y. (Ed.). (2014). Safe management of wastes from health-care activities. World Health Organization .

Cheng, Y. W., Sung, F. C., Yang, Y., Lo, Y. H., Chung, Y. T., \& Li, K. C. (2009). Medical waste production at hospitals and associated factors. Waste Management, 29(1), 440-444 .

Coker, A., Sangodoyin, A., Sridhar, M., Booth, C., Olomolaiye, P., \& Hammond, F. (2009). Medical waste management in Ibadan, Nigeria: Obstacles and prospects. Waste management, 29(2), 804811 .

Debere, M. K., Gelaye, K. A., Alamdo, A. G., \& Trifa, Z. M. (2013). Assessment of the health care waste generation rates and its management system in hospitals of Addis Ababa, Ethiopia, 2011. BMC Public Health, 13(1), 28.

Dehghani, M. H., Azam, K., Changani, F., \& Fard, E. D. (2008). Assessment of medical waste management in educational hospitals of Tehran University Medical Sciences. Journal of Environmental Health Science \& Engineering, 5(2), 131-136.

Demirbas, A. (2011). Waste management, waste resource facilities and waste conversion processes. Energy Conversion and Management, 52(2), 1280-1287 .

Diaz, L. F., \& Savage, G. M. (2003). Risks and costs associated with the management of infectious wastes .

Dohare, S., Garg, V. K., \& Sarkar, B. K. (2013). A study waste management status in health farcicalities of an urban area. International Journal of Pharma and Bio Sciences, 4, 1107-12.

Eleyan, D., Al-Khatib, I. A., \& Garfield, J. (2013). System dynamics model for hospital waste characterization and generation in developing countries. Waste Management \& Research, 31(10), 986-995 .

Fu, F., \& Wang, Q. (2011). Removal of heavy metal ions from wastewaters: a review. Journal of environmental management, 92(3), 407-418 .

Jasem M. Alhumoud and Hani M. Alhumoud. An analysis of trends related to hospital solid wastes management in Kuwait. Management of Environmental Quality: An International Journal Vol. 18 No. 5, 2007.

Komilis, D., \& Katsafaros, N. (2011). Statistical predictors of hazardous medical waste generation rates in a 40-bed general hospital. Global NEST Journal, 13(2), 170-175.

Komilis, D., Fouki, A., \& Papadopoulos, D. (2012). Hazardous medical waste generation rates of different categories of health-care facilities. Waste Management, 32(7), 1434-1441 .

Kudoma, B. (2013). An evaluation of clinical waste management in Gaborone city council healthcare facilities (Unpublished Doctoral Thesis). University of South Africa, Pretoria .

Kumari, R., Srivastava, K., Wakhlu, A., \& Singh, A. (2013). Establishing biomedical waste management system in Medical University of India-A successful practical approach. Clinical epidemiology and global health, 1(3), 131-136. 
Mohan, D. R., Prasad, M. V., \& Kumar, K. S. (2012). Impact of training on bio medical waste management-A study and analysis. EXCEL International Journal of Multidisciplinary Management Studies, 2(6), 69-80.

Mohee, R. (2005). Medical wastes characterisation in healthcare institutions in Mauritius. Waste management, 25(6), 575-581.

Muduli, K., \& Barve, A. (2012). Barriers to green practices in health care waste sector: an indian perspective. International Journal of Environmental Science and Development, 3(4), 393.

Nwachukwu, N. C., Orji, F. A., \& Ugbogu, O. C. (2013). Health care waste management-public health benefits, and the need for effective environmental regulatory surveillance in federal Republic of Nigeria. In Current Topics in Public Health. InTech .

Pichtel, J. (2005). Waste management practices: municipal, hazardous, and industrial. CRC press.

Prüss, A., Emmanuel, J., Stringer, R., Pieper, U., Townend, W., Wilburn, S., Chantier, Y. \& World Health Organization 2013, "Safe management of wastes from health-care activities .

Saini, R.S. \& Dadhwal, P.J.S. Clinical waste management: a case study. Journal of Indian Association for Environmental Management, , (1995) 22, 172-174 .

Sarsour, A., Ayoub, A., Lubbad, I., Omran, A., \& Shahrour, I. (2014). Assessment of medical waste management within selected hospitals in Gaza strip Palestine: A pilot study. International Journal of Scientific Research in Environmental Sciences, 2(5), 164.

Schwartz, R. N., Eng, K. J., Frieze, D. A., Gosselin, T. K., Griffith, N., Seung, A. H., ... \& Szabatura, A. H. (2010). NCCN task force report: specialty pharmacy. Journal of the National Comprehensive Cancer Network, 8(Suppl 4), S-1 .

World Health Organization, (WHO). 2004. Decision making guide" Management of solid healthcare waste at primary healthcare centers" ISBN 9241592745.

Yong, Z., Gang, X., Guanxing, W., Tao, Z., \& Dawei, J. (2009). Medical waste management in China: a case study of Nanjing. Waste management, 29(4), 1376-1382. 